\title{
EMPIRICAL TESTING OF KOTLER'S HIGH-PERFORMANCE FACTORS TO INCREASE SALES GROWTH
}

\author{
Oren Dayan: Nelson Mandela Metropolitan University \\ Cecil Arnolds: Nelson Mandela Metropolitan University \\ Miemie Struwig: Nelson Mandela Metropolitan University
}

\begin{abstract}
SYNOPSIS
Purpose and/or objectives

The primary objective of this study is to empirically test Kotler's (2003) high-performance model which ensures an increase in sales growth. More specifically, the study explores the influence of process variables (as measured by marketing strategies), resources management (as measured by the management of labour, materials, machines, information technology and energy) and organisational variables (as measured by TQM and organisational culture) on sales growth in the food, motorcar and high-technology manufacturing industries
\end{abstract}

\section{Problem investigated}

Various research studies suggest that the managers of firms are continuously challenged in their attempts to increase their sales (Morre, 2007; Pauwels, Silva Risso, Srinivasan \& Hanssens, 2004: 142-143; Gray \& Hayes, 2007: 1). Kotler (2003) suggests a model that leads to a high performing business. The question is posed as to whether this model can be used to increase sales growth in all businesses. This study seeks to develop a generic model to increase sales growth across industries by using an adapted version of Kotler's (2003) high-performance model. The study investigates the application of this adapted model on the food, motorcar and high-technology manufacturing industries.

\section{Design and/or methodology and/or approach}

An empirical causal research design that includes 770 marketing and product development practitioners from multinational food, motorcar and high-technology manufacturing firms, was used in this study. A response rate of $76.1 \%$ was achieved as only 571 useable questionnaires were returned.

The internal reliability and discriminant validity of the measuring instrument were assessed by the calculation of Cronbach alpha coefficients and the conducting an exploratory factor analysis respectively. Structural Equation Modelling SEM) was used to statistically test the relationships between the independent variables (marketing strategies, resource management, TQM and organisational culture) and the dependent variable (sales growth).

\section{Findings and/or implications}

As the achievement of increased sales, profits and market share is important to all industries, companies spend large amounts of money on research and development to increase sales and market share. The study's empirical results lead to a proposed model that shows the factors influencing sales growth. These factors include distribution channel development, third-party agreements, ebusiness, e-savings and a market-oriented organisational culture.

KEY WORDS: Sales growth, marketing strategies, organisational culture

\section{ABSTRACT}

The study investigates sales growth by empirically testing three factors of Kotler's (2003) high-performance model, namely processes, management of resources and organisational variables. The sample included 571 marketing and product development practitioners and structural equation modelling was used to test the 
relationships among the variables. The results indicated that not all the variables in the three factors statistically influenced sales growth. Resources were discarded as a factor during the data analysis as it lacked sufficient discriminate validity. For the process factor, various combinations of marketing strategies (distribution-channel development, product image, third-party agreements, pricing, e-business and e-save) showed statistically significant relationships with sales growth. In the organisational factor, only market culture was found to be important to achieve increased sales growth. Based on the empirical results, a model is proposed that identifies the factors that will influence sales growth in the food, motorcar and hightechnology manufacturing industries.

\section{INTRODUCTION}

The success of any business is generally associated with achieving its triple bottom line and business goals (such as profitability, return on investment and the maximisation of shareholders' wealth) as well as increasing its market share. Sales growth is an important indicator of business success (Kotler, 2003). According to Shaw and Merrick (2005: 39), sales growth is marketing managers' most common criteria for measuring the effectiveness of their marketing function in a business. Sales growth is defined in this study as the perceived extent to which a firm achieves sales targets, increases market share and generates sales of products with long-term profitability. However, whatever the approach to business success, this study asserts that the triple bottom line and business success will only be achieved by a high-performing business.

A high-performance business, according to Kotler (2003: 63), is one that creates customer value and customer satisfaction through the effective management of four key factors, namely, stakeholders, processes, resources and organisation (See Figure 1). Stakeholders refer to the shareholders, customers, employees, suppliers and distributors on which firms must focus to achieve a high performing firm. The process factors include new-product development, customer attraction and order fulfilment and thus relates to marketing strategy. Resource management refers to how a firm manages its labour, material, machine, information and energy resources. The final factor necessary to achieve high performance is the nature of the organisation, which includes the firm's structures, policies and organisational culture (Seiler \& Gurewitsch, 2005; Kotler, 2003). Organisational culture, among others, has been identified as a key factor influencing a manager's efficacy, organisational commitment, customer loyalty, customer satisfaction and increased sales (Torvald, Svein \& Einar, 2005: 31).

This study will empirically test the Kotler's (2003) high-performance model. By critically analysing the Kotler's (2003) high-performance model, a conceptual model is designed. Thereafter the methodology used to test the conceptual model empirically, is explained, the results are discussed and conclusions given.

\section{PROBLEM STATEMENT}

Various research studies suggest that the managers across industries are continuously challenged in their attempts to increase their sales (Morre, 2007; Pauwels, Silva Risso, Srinivasan \& Hanssens, 2004: 142-143; Gray \& Hayes, 2007: 1). A great deal of uncertainty exists among marketing practitioners as to what marketing strategies to follow in order to increase their sales. For example, in the motorcar manufacturing industry, Schneider, Schade and Grupp (2004: 148), as well as Hanssens and Leeflang (2005: 423) call for a redirection of strategic marketing approaches due to the proliferation of motorcar models, engines, transmissions and other vehicle-related systems that often confuse consumers. Dignan (2006: 40), Thibodeau (2006: 14) and Morre (2007) reported on huge financial losses in the USA high-technology industry due to deficient or lack of innovative marketing strategies. Guyer (2006: 28) and McElroys (2005: 21) call for more research on the most effective marketing strategies to engage consumers in general. There is thus a need to develop an empirically tested model to achieve sales growth in businesses. Against this background, the present study investigates an adapted version of Kotler's (2003) high-performance model in order to investigate the factors that will increase sales growth. 


\section{LITERATURE REVIEW}

This study asserts that the triple bottom line and business goals (profitability, return on investment, shareholders' wealth, socio-economic performance, productivity, sales growth and market share) will only be achieved by a high-performing business. Kotler's (2003) high-performance business model is therefore the basis for this study. Kotler's (2003) high-performance model is graphically illustrated in Figure 1.

FIGURE 1: KOTLER'S HIGH-PERFORMANCE MODEL

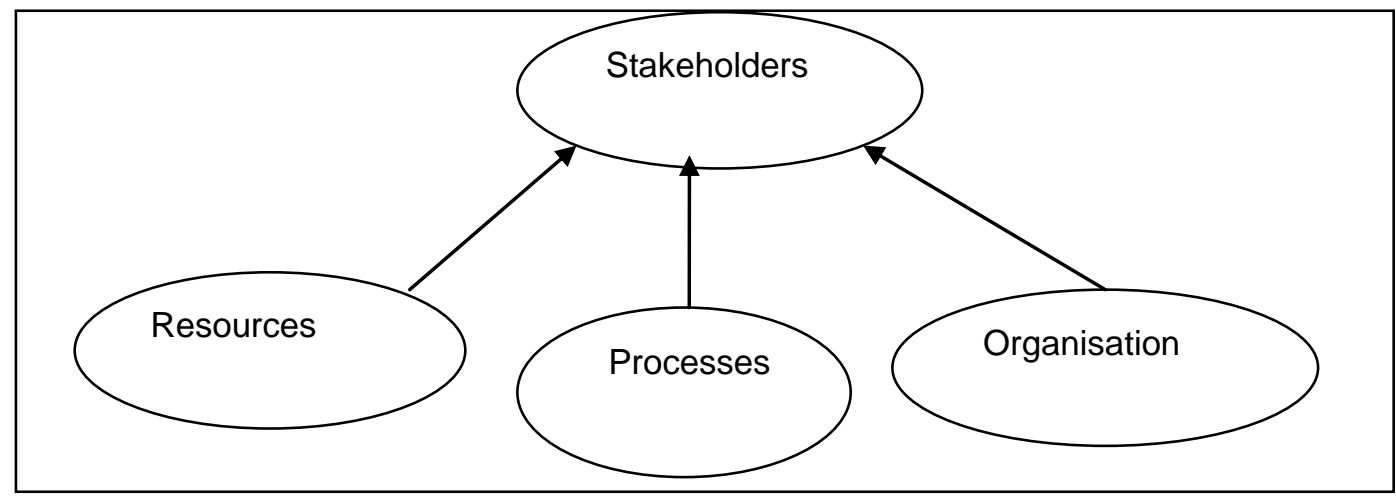

Source: Researcher's own construct as adapted from Kotler (2003: 66)

From Figure 1 it is clear that the Kotler's (2003) model comprises the following factors: stakeholders, processes, resources and organisation. Sales growth would be achieved depending on how effectively these factors are managed.

\section{Customer as the key stakeholders}

As far as stakeholders are concerned, the present study agrees with Kotler (2003) and suggests that the customer is "king". The end result of a high-performance model would therefore be a satisfied customer who will reward a high-performance firm with repeat purchases, in other words, increased sales.

\section{Marketing strategies as key processes}

In terms of processes, the present study single out marketing strategies as the critical process in pursuing sales growth. Generally, marketing strategies involve the 4Ps of marketing, namely product, promotion, price and place strategies. Each strategy consists of various tactics used in marketing the product or service. A product strategy would for example include tactics such as visual design, product support and technological innovation. In a similar fashion, media releases, coupons, club membership would be tactics employed in a promotion campaign.

\section{Product marketing strategy}

It has been reported that product marketing tactics such as branding, product support services, and product design and innovation lead to an increase in sales via customer satisfaction (Lancaster \& Reynolds, 2004: 137-138; Jobber, 1998: 210; Subhash, 1993: 380). Research also shows that support centres, which coordinate incoming product enquiries and outgoing product support, increase sales growth (Reyes, 2004: 6). Simonson (1999) reported that product marketing tactics such as visual design, product quality and technological innovation, exert a positive influence on purchasing decisions of retailers, while DelVecchio, Zemanek, Mcntyre and Claxton (2003: 15) found that sharing product development information with customers, as a product marketing tactic, influences sales growth positively. 
Soraya (2006: 16) reported that product marketing tactics such as the use of nostalgic brand names and designs are positively related to customer loyalty and sales growth eventually. Sales growth is also positively related to linking new products to existing brands (Palmer, 2000: 419).

\section{Promotion strategy}

Modern marketing requires more than just good and well-developed products, attractive prices and availability to the target customers. Firms must also employ one or more of a variety of promotion tactics, including advertising campaigns (Fitzgerald, 2007) online promotion campaigns (Callaghan, 2003: 31), direct sales, media releases, published articles in journals and advertising on the Internet (Percy, Rossiter \& Elliott, 2001: 217), free samples, coupons, club membership (Kryhul, 2000: 13) and trade-ins (Frymier \& Rixey, 2000). In addition, Smith (1997) found a significant positive relationship between promotion tactics such as entertainment events, web communications and higher sales volumes.

\section{Price strategy}

Price is one of the most important ingredients in the business process. If the pricing strategy is wrong, the business can easily fail, but if the pricing strategy is right, the business can be both profitable and growing. Despite the findings of Gourville and Soman (2002: 92) that penetration pricing, predatory pricing, discounts and allowances do not increase short-term demand for products, most of the empirical research results suggest a positive relationship between the use of price tactics, such as discounts, allowances, predatory pricing, penetration pricing, skimming pricing, demand pricing, value-based pricing and increased sales (Percy, et al, 2001: 219; Palmer 2000: 422; Danaher, Hardie, Putsis \& Williams, 2001: 52; Silva-Risso \& Bucklin, 1999: 72).

\section{Place (distribution) strategy}

Effective distribution channels make products available to existing and potential customers, which lead to an increase in sales (Lancaster \& Reynolds, 2004: 191; Kotler, 2003: 519; Subhash, 1993: 470). Banson (2002: 17) reported a significant positive relationship between an investment in the training of agents in distribution channels and the long-term economic profitability of firms. Weernink (2000) found a marginally positive relationship between using Original Equipment Manufacturers (OEM) agreements and a firm's profitability, while Bucklin and Sunil (1998: 213) found a strong relationship between the use of distribution tactics, such as training new distribution channels, targeting specific niches, incentives for distributors and the competitive advantage of firms.

\section{TQM and organisational culture as key organisational variables}

Total quality management (TQM) has emerged and remained a dominant theme in management thinking over the past fifty years (Beckford, 2002: 5). According to Kotler (2003: 84), TQM is the key to value creation, as it is central to customer satisfaction. Daft (2006) concurs that quality, together with costs, speed and innovation, are important drivers of a firm's competitiveness. Chinho and Shofang (2006) also acknowledge TQM as a competitive advantage for any firm. TQM practices such as ISO certification (Han, Chen \& Ebrahimpour, 2007: 15-16), Six Sigma (Chomka, 2003: 60; Gazit, 2002: 38) and bench marking (APQC, 2007; Evans \& Dean 2003) have been reported to improve sales growth and overall business performance. TQM is therefore an important organisational variable in achieving a high-performance business and is included in the conceptual model to increase sales growth in the present study.

Furthermore, Thompson, Strickland and Gamble (2007) emphasise that organisational culture is critical for achieving strategic objectives of businesses. It is widely accepted that businesses with a positive organisational culture are more likely to survive in a competitive environment and should have higher performance than organisations with a negative organisational culture (Plumeri, 2006: 6; Hill \& Jones, 2004: 419). Torvald et al. (2005: 31) concur that there is a positive relationship between organisational culture, manager's efficacy and organisational commitment, and that these cultural aspects are related to performance variables such as loyalty, customer satisfaction and additional sales. The positive relationship 
between organisational culture and enhanced business performance is also supported by the studies of Thomas and Lindsay (2003: 48), Chow and Shan (2007: 52) and Sandler and Blanck (2005: 59).

Hellriegel, Jackson and Slocum (2004) and Kotler (2003) identify two types of organisational culture that are closely associated with business success, namely entrepreneurial and market-oriented culture. An entrepreneurial-organisational culture is defined as a firm's inclination to risk taking, dynamism and creativity (Hellriegel et al., 2004; Kotler, 2003). A market-organisational culture, on the other hand, is defined as a firm's commitment to hard-driving competitiveness and profitability. A market-oriented culture is driven by quarterly and annual goals to deliver what the market wants and to increase market share (Weber, 2008; Kotler, 2003: 69). To improve business performance, it is important for businesses to analyse their markets for the degree of market saturation, the number of competitors, the market growth rate and the average penetration level of new products into the market segment or equivalent niche. A market-orientated organisational culture is therefore important to achieve sales growth as a business goal.

\section{Resource management as a key variable}

Finally, Kotler (2003) advises that another key to high-performance businesses is the owning (via acquisition or outsourcing) and nurturing of core resources, such as labour, information technology, machines and equipment, and energy (gas, wind and electricity). Manufacturing and delivering the goods and services to customers at the right time and place are also unthinkable without the machinery and technology used in inbound processes, production outbound logistics of firms (Casper, 2007: 32). Studies have also found that proper hiring, training and retaining of staff can lead to sales gains (Sullivan, 2007: 41-42; Kooser, 2007: 12; Shermach, 2006: 20). The proper management of resources is therefore important for increasing sales growth (Russell 2006: 14; Karpinski, 2004: 26) and is therefore included as a key variable in the present study's conceptual model to increase sales growth in firms.

\section{RESEARCH OBJECTIVES AND HYPOTHESES}

The primary objective of this study is to empirically test an adapted version of Kotler's (2003) highperformance model to increase sales growth in three selected manufacturing industries (food, motorcar and high-technology). More specifically, the study explores the influence of process variables (marketing strategies), resources management and organisational variables (TQM and organisational culture) on sales growth. The study aims to clarify the factors that will increase sales in the selected industries.

To achieve the above-mentioned objective and in line with the preceding literature review, the following hypotheses were formulated:

$\mathrm{H} 1: \quad$ Product strategy exerts a positive influence on sales growth

H2: $\quad$ Promotion strategy exerts a positive influence on sales growth

H3: $\quad$ Pricing strategy exerts a positive influence on sales growth

H4: $\quad$ Place strategy exerts a positive influence on sales growth

H5: $\quad$ Resource management exerts a positive influence on sales growth

H6: $\quad$ TQM exerts a positive influence on sales growth

H7A: Entrepreneurial organisational culture exerts a positive influence on sales growth

H7B: Market-oriented organisational culture exerts a positive influence on sales growth

\section{METHODOLOGY OF THE STUDY}

This study followed a quantitative research paradigm (Struwig \& Stead, 2001). More specifically, the study used a causal research approach to empirically test the hypothesised relationships. The study asserts that the variables included are well-known management concepts, but that the relationships between these variables have not been tested at a rigorous statistical level such as structural equation modelling. By 
conducting such an assessment, the study would make an important contribution in forwarding a causal model of factors that will increase sales growth in firms.

\section{The measuring instrument}

The Arnolds, Tait and Dayan (2006) instruments were used to measure the product, price, promotion and place strategies. Questionnaire items were however added to improve the measuring instrument and to make provision for new tactics that were not included in the Arnolds et al. (2006) study. A self-constructed scale based on literature and interviews with marketing managers who promote the TQM model in their firms was used to measure TQM effectiveness. The instrument consisted of eleven items and captured elements such as: Six-Sigma, benchmarking and other quality improvement techniques and general quality management philosophy. Responses were anchored to a five-point scale ranging from (1) strongly disagree to (5) strongly agree. An instrument was constructed to measure the cultural orientation of business. The eight market culture items capture perceptions on achieving market and financial goals as well as competitiveness, while the nine entrepreneurial culture items measure perceptions on organisational characteristics such as risk taking, employees' interaction, flexibility, dynamism and creativity. The instrument was anchored to a five-point scale ranging from (1) strongly disagree to (5) strongly agree. A seven-item instrument was constructed to measure the variable 'resource management'. This instrument measured respondents' perceptions, for example, of the extent to which their firms invest in improving skills of employees, use the most appropriate equipment and possess or have available the necessary energy sources to achieve their business objectives. The instrument was anchored to a five-point scale ranging from (1) strongly disagree to (5) strongly agree. The sales success scale of Arnolds et al. (2006) was adopted for the purpose of measuring sales growth. The Arnolds et al. (2006) instrument produced a Cronbach alpha of 0.870 and a high level of discriminate validity. The instrument statements were anchored by a five-point scale ranging from (1) strongly disagree to (5) strongly agree.

A pilot survey of 60 senior marketing managers of high-technology, food and motorcar manufacturing firms were done to see whether the respondents had any problems to answer the questionnaire. Based on the questionnaire responses, minor corrections were needed. The preliminary questionnaire was tested for content validity by circulating it to three academics in the field. The instrument was then ready for use.

\section{Data collection}

A data base of 770 multinational food, motorcar and high-technology manufacturing firms which had successfully launched products in the global market, was used in this study. It was decided to target all the companies in the database and not to draw a sample from it. The targeted companies included chief executive officers, marketing directors and marketing managers located in multinational companies all over the world. Seven hundred and seventy questionnaires were distributed. A total of 571 usable questionnaires were returned, which represents a response rate of $76.1 \%$. The respondent companies, included firms where the lowest turnover per annum was 46.6 million USD, while the lowest number of staff employed by these firms was 350. Table 1 outlines the demographics of the respondents.

Table 1: demographic composition of the respondents

\begin{tabular}{|l|l|l|l|}
\hline $\begin{array}{l}\text { DEMOGRAPHIC } \\
\text { VARIABLE }\end{array}$ & & $\begin{array}{l}\text { FREQUENCY } \\
(\mathbf{n})\end{array}$ & $\begin{array}{l}\text { PERCENT } \\
(\%)\end{array}$ \\
\hline \multirow{4}{*}{ Industry } & Motorcar & 193 & $33.7 \%$ \\
\cline { 2 - 4 } & High-technology & 196 & $34.3 \%$ \\
\cline { 2 - 4 } & Food & 183 & $32.0 \%$ \\
\cline { 2 - 4 } & TOTAL & $\mathbf{5 7 2}$ & $\mathbf{1 0 0 . 0 \%}$ \\
\hline \multirow{3}{*}{ Gender } & Male & 413 & $72.2 \%$ \\
\cline { 2 - 4 } & Female & 159 & $27.8 \%$ \\
\cline { 2 - 4 } & TOTAL & $\mathbf{5 7 2}$ & $\mathbf{1 0 0 . 0} \%$ \\
\hline
\end{tabular}




\begin{tabular}{|c|c|c|c|}
\hline $\begin{array}{l}\text { DEMOGRAPHIC } \\
\text { VARIABLE }\end{array}$ & & $\begin{array}{l}\text { FREQUENCY } \\
(\mathrm{n})\end{array}$ & $\begin{array}{l}\text { PERCENT } \\
(\%)\end{array}$ \\
\hline \multirow[t]{6}{*}{ Age } & $20-29$ & 120 & $21.0 \%$ \\
\hline & $30-39$ & 297 & $51.9 \%$ \\
\hline & $40-49$ & 137 & $24.0 \%$ \\
\hline & $50-59$ & 18 & $3.1 \%$ \\
\hline & $60+$ & 0 & $0.0 \%$ \\
\hline & TOTAL & 572 & $100.0 \%$ \\
\hline \multirow{5}{*}{$\begin{array}{l}\text { Educational } \\
\text { qualification }\end{array}$} & Matric & 29 & $5.1 \%$ \\
\hline & Diploma & 72 & $12.6 \%$ \\
\hline & First degree or equivalent & 356 & $62.2 \%$ \\
\hline & Second degree or equivalent & 115 & $20.1 \%$ \\
\hline & TOTAL & 572 & $100.0 \%$ \\
\hline \multirow[t]{8}{*}{ Geographic area } & Africa & 29 & $5.1 \%$ \\
\hline & Asia & 38 & $6.7 \%$ \\
\hline & Europe & 106 & $18.5 \%$ \\
\hline & Middle East & 322 & $56.3 \%$ \\
\hline & North America & 39 & $6.8 \%$ \\
\hline & South America & 22 & $3.8 \%$ \\
\hline & South East Asia and Oceania & 16 & $2.8 \%$ \\
\hline & TOTAL & 572 & $100.0 \%$ \\
\hline \multirow[t]{6}{*}{ Position } & President $\backslash$ CEO & 29 & $5.0 \%$ \\
\hline & $\begin{array}{l}\text { Marketing director / sales } \\
\text { director }\end{array}$ & 77 & $13.5 \%$ \\
\hline & Regional sales manager & \begin{tabular}{|l|}
155 \\
\end{tabular} & $27.1 \%$ \\
\hline & $\begin{array}{l}\text { Product manager or product } \\
\text { marketing manager }\end{array}$ & 247 & $43.2 \%$ \\
\hline & Marketing consultant & 64 & $11.2 \%$ \\
\hline & TOTAL & 572 & $100.0 \%$ \\
\hline \multirow{6}{*}{$\begin{array}{l}\text { Experience in } \\
\text { present occupation }\end{array}$} & Less than 3 years & 93 & $16.3 \%$ \\
\hline & 3 to 5 years & 219 & $38.3 \%$ \\
\hline & 5 to 8 years & 156 & $27.3 \%$ \\
\hline & 8 to 10 years & 58 & $10.1 \%$ \\
\hline & More than 10 years & 46 & $8.0 \%$ \\
\hline & TOTAL & 572 & $100.0 \%$ \\
\hline \multirow{6}{*}{$\begin{array}{l}\text { Working for } a \\
\text { current employer }\end{array}$} & Less than 3 years & 230 & $40.2 \%$ \\
\hline & 3 to 5 years & 211 & $36.9 \%$ \\
\hline & 5 to 8 years & 80 & $14.0 \%$ \\
\hline & 8 to 10 years & 30 & $5.2 \%$ \\
\hline & More than 10 years & 21 & $3.7 \%$ \\
\hline & TOTAL & 572 & $100.0 \%$ \\
\hline
\end{tabular}

From Table 1 it is clear that the majority of the respondents $(51.9 \%)$ were in the age group 30 to 39 , had a first degree (62.2\%) and were from the Middle East (56.3\%). 


\section{Data analysis}

Various data analysis procedures were conducted, including testing for the reliability and validity (exploratory and confirmatory factor analyses) of the measuring instruments, testing for normal distribution of the data and structural equation modelling.

\section{Reliability of the measuring instruments}

The first step in the data analysis procedure was to assess the internal reliability of the measuring instruments by means of Cronbach alpha coefficients. The results, reported in Table 2, show that all the instruments returned alpha values of 0.50 and more, which are acceptable for basic research (Tharenou 1993; Pierce \& Dunham 1987). The present study qualifies for basic research, as no previous study has been done on the path models investigated in this study.

Table 2: cronbach alpha values of measuring instruments

\begin{tabular}{|l|l|}
\hline MEASURING INSTRUMENT & ALPHA VALUE \\
\hline Sales growth & 0.71 \\
\hline Entrepreneurial organisational culture & 0.84 \\
\hline Market-oriented organisational culture & 0.75 \\
\hline Total Quality Management & 0.65 \\
\hline Resource management & 0.50 \\
\hline Product marketing strategy & 0.51 \\
\hline Price strategy & 0.52 \\
\hline Promotion strategy & 0.73 \\
\hline Place strategy & 0.50 \\
\hline
\end{tabular}

\section{Validity of the measuring instruments}

The discriminant validity of the measuring instruments was assessed by conducting an exploratory factor analysis. The Kaiser-Meyer-Olkin Measure of sampling adequacy and Bartlett's test of sphericity were however conducted first to ascertain whether a factor analysis could be conducted on the data. Table 3 indicates the factor analysability of the sample as measured by the above-mentioned tests. The KaiserMeyer-Olkin (KMO) and Bartlett's tests are measured on a scale ranging from nil (0) to one (1), with high scores (above 0.5) indicating a high level of acceptability in the KMO's case, while low scores (below 0.5 ) on Bartlett's test indicate a high level of acceptability. The results show that both the KMO and Bartlett tests indicate that the data are factor analysable.

Table 3: kmo measure of sampling adequacy and bartlett's test of sphericity

\begin{tabular}{|l|l|l|}
\hline VARIABLE & KMO TEST & BARTLETT'S TEST \\
\hline Marketing strategies & 0.678 & $0.000^{\star \star *}$ \\
\hline $\begin{array}{l}\text { TQM, organisational culture } \\
\text { variables and resources } \\
\text { management }\end{array}$ & 0.747 & $0.000^{\star \star \star}$ \\
\hline Sales growth & 0.721 & $0.000^{\star \star *}$ \\
\hline
\end{tabular}

Note: ${ }^{* *}=$ significance at $p<0.001$

The exploratory factor analyses were conducted using the SPSS statistical software package (SPSS 15.0 for Windows, 2006). Principal Component Analysis was specified as the method of factor extraction and Varimax rotation of the original factor matrix was used in all instances. 
In the first instance, namely the factor analysing of the marketing strategies, the extraction of four factors, namely product, price, promotion and place marketing strategies, was specified. It was surmised that each of the four variables modelled was a separate and distinct construct but that their "separateness" needed to be empirically verified. The resultant empirical evidence did not, however, support this contention. After considering various options ranging from four to seven factor solutions, it had to be concluded that the instrument used to measure the marketing strategies did not demonstrate sufficient evidence of discriminant validity. Six, instead of four, distinctly separate launching strategies could be identified, namely distribution channel development, product image, e-business, pricing, e-saving and third-party agreements.

The second set of exploratory factor analyses considered the separateness of the organisational variables. Four factors, namely entrepreneurial organisation culture, market-orientated organisation culture, total quality management and resource management, were extracted. The empirical evidence does not support the surmised four variables as suggested in the literature. Three distinctly separate organisational variables could be identified, namely entrepreneurial organisation culture, market-orientated organisation culture and total quality management. The resource management variable did not emerge as a separate variable. No factor analysis was conducted for the sales growth variable, as it was the only dependent variable included in the theoretical model. The most interpretable factor structure of the two sets of exploratory factor analyses, as well as the re-calculated reliability coefficient, is reported in Table 4 . The Cronbach alpha values of all the latent variables exceed the 0.50 cut-off point needed for basic research (Tharenou 1993; Pierce \& Dunham 1987).

Table 4: empirical factor structure of the latent variables

\begin{tabular}{|c|c|c|}
\hline LATENT VARIABLE & MEASUREMENT ITEMS & $\begin{array}{l}\text { CRONBACH } \\
\text { ALPHA }\end{array}$ \\
\hline $\begin{array}{ll}\text { Distribution } & \text { channel } \\
\text { development } & \end{array}$ & $\begin{array}{l}\text { PLAC 2, 3, } 5 \\
\text { PROM 10,15 } \\
\text { PROD 3 }\end{array}$ & 0.66 \\
\hline Product image & $\begin{array}{l}\text { PROD 5, 7, 8, } 13 \\
\text { PROM } 11 \\
\text { PLAC } 6\end{array}$ & 0.67 \\
\hline E-business & $\begin{array}{l}\text { PROM 1, 3, 4, 6, } 7 \\
\text { PROD } 2\end{array}$ & 0.66 \\
\hline Pricing & $\begin{array}{l}\text { PRIC 2, 7, 8, } 9 \\
\text { PROD 6 } \\
\text { PLAC } 7\end{array}$ & 0.61 \\
\hline E-saving & $\begin{array}{l}\text { PRIC 1, } 5 \\
\text { PLAC } 10\end{array}$ & 0.62 \\
\hline Third-party agreements & $\begin{array}{l}\text { PROM 12, } 13 \\
\text { PLAC 8, } 9\end{array}$ & 0.56 \\
\hline $\begin{array}{l}\text { Entrepreneurial organisational } \\
\text { culture }\end{array}$ & $\begin{array}{l}\text { RESOU } 1,5 \\
\text { TQM } 1,4,5,7,8,9 \\
\text { CULT 2, 6, 7, 9, 10, } 15\end{array}$ & 0.79 \\
\hline TQM & $\begin{array}{l}\text { TQM 2, 6, } 11 \\
\text { RESOU 3, } 7 \\
\text { CULT 5 }\end{array}$ & 0.65 \\
\hline $\begin{array}{l}\text { Market-oriented } \\
\text { organisational culture }\end{array}$ & $\begin{array}{l}\text { CULT 3, 4, 13, 16, } 17 \\
\text { RESOU } 6\end{array}$ & 0.52 \\
\hline Sales growth & SGRO 1, 2, 3, 4, 5, 6 & 0.70 \\
\hline
\end{tabular}

\section{Revised hypothesised model}


The theoretical models needed to be revised after the omission and reconstruction of the various variables in the model. The revised hypotheses were formulated as follows:

H1A: Product strategy (as measured by product image) exerts a positive influence on sales growth

H2A: Promotion strategy (as measured by e-business) exerts a positive influence on sales growth

$\mathrm{H} 3 \mathrm{~A}$ : Pricing strategy exerts a positive influence on sales growth

H4A1: Place strategy (as measured by distribution channel development) exerts a positive influence on sales growth

H4A2: Place strategy (as measured by third-party agreements) exerts a positive influence on sales growth

H4A3: Place launching strategy (as measured by e-saving) exerts a positive influence on sales growth

H6A1: TQM exerts a positive influence on sales growth

H7A1: Entrepreneurial organisational culture exerts a positive influence on sales growth

H7A2: Market organisational culture exerts a positive influence on sales growth

There is no revised hypothesis with regard to the resource management variable as this variable did not show sufficient discriminate validity. 
Figure 2: the revised hypothesised model

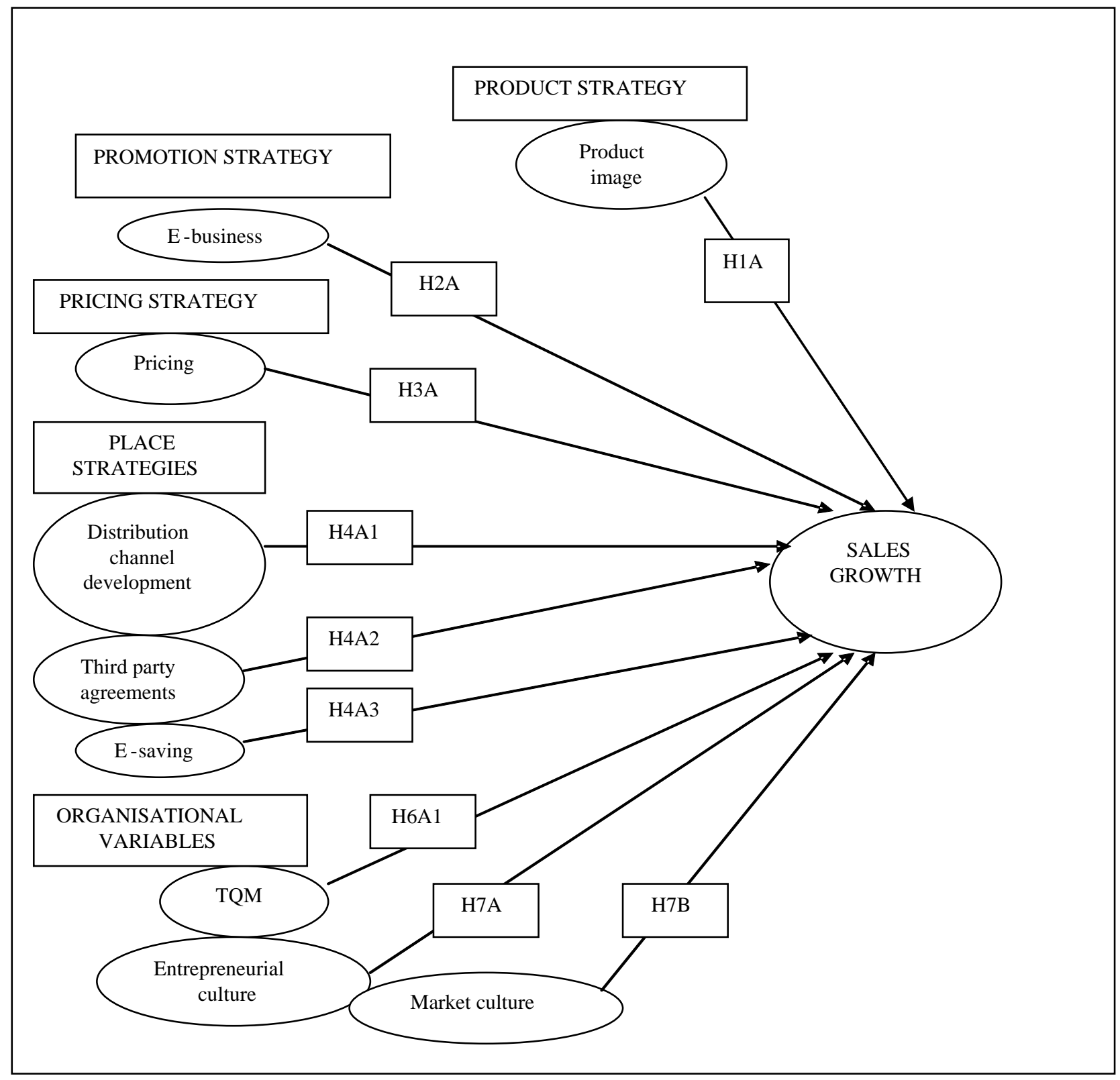

All subsequent analyses were based on the revised hypotheses. These revised hypotheses are graphically illustrated in Figure 2. 


\section{Assessment of normal distribution of the data}

Before structural equation modelling could be conducted, the normal distribution of the data needed to be assessed. The normal distribution of the data was assessed by means of a test for (a) univariate and (b) multivariate normality. For both these analyses the t-values were calculated to assess skewness (measurement of symmetry) and kurtosis (measurement of peakedness or flatness) of the data. The results indicate that the data in both the univariate and multivariate analyses are skewed and not peaked. Thus, the conclusion is that the data did not demonstrate sufficient evidence of normality. It is also further concluded that the normal Maximum Likelihood technique could not be used and that the Robust Maximum Likelihood technique had to be used in all subsequent CFA and SEM analyses (Jöreskog \& Sörbom, 2004).

\section{Confirmatory factor analysis (CFA)}

A Confirmatory Factor Analysis (CFA) was conducted by using the LISREL statistical software package (Jöreskog \& Sörbom, 2004). This analysis sought to establish further evidence of construct validity by confirming the empirical factor structure (see Table 4) that emerged from the exploratory factor analyses. The goodness-of-fit indices of the CFA are shown in Table 5. The completely standardised solution for LAMBDA-X matrix was inspected, which indicated that the CFA results represent a permissible solution. The results show that both the CFA and LAMBDA-X solutions provide further evidence of construct validity.

Table 5: results of the confirmatory factor analysis

\begin{tabular}{|l|l|l|l|}
\hline $\begin{array}{l}\text { SAMPLE SIZE } \\
\text { EXCEEDANCE }\end{array}$ & SATORRA-BENTLER CHI-SQUARE & Df & PROBABILITY \\
\hline 571 & 6988.987 & 1874 & 0.000 \\
\hline \multicolumn{2}{|l|}{ Root mean square error of approximation (RMSEA) $=0.069$} \\
\hline
\end{tabular}

The indices of fit depicted in Table 5 indicate reasonable fit. According to MacCullum, Browne and Sugawara (1996), an RMSEA value of between 0.05 and 0.08 indicates a reasonable fit of the empirical factor structure to the data. The Chi-square $(6988.987, p<0.001)$ shows that the null hypothesis, that the empirical factor structure does not fit the data, is rejected. It must therefore be concluded that the empirical factor structure that emanated from the exploratory factor analysis constitutes a reasonable fit to the data.

The modification indices were inspected and there was no reason to make adjustments to the measurement model. On this basis, structural equation modelling (SEM) could then be conducted on the measurement model.

\section{Structural equation analysis}

Structural equation analysis or modelling (SEM) is a statistical data analysis technique that seeks to explain the relationships among multiple variables. It does this by examining the structure of interrelationships expressed in a series of multiple regression equations (Hair, Black, Babin, Anderson \& Tatham, 2006: 711). Structural equation models are more advanced than ordinary regression models, as they incorporate multiple dependent and independent variables as well as the hypothetical latent constructs which are represented by clusters of observed variables. The model also provides a way to test the specified set of relationships among observed and latent variables as a whole and allows theory testing even when experiments are not possible (Cooper \& Schindler, 2006: 584; Savalei \& Bentler, 2006: 330). Unlike other multivariate techniques, which are limited to representing only a single relationship between the dependent and independent variables, SEM can measure multiple and interrelated dependence relationships simultaneously, provide for the controlling of extraneous and confounding variables and account for measurement error in the estimation process (Cooper \& Schindler, 2006). 
Figure 3: influence of marketing strategies on sales growth

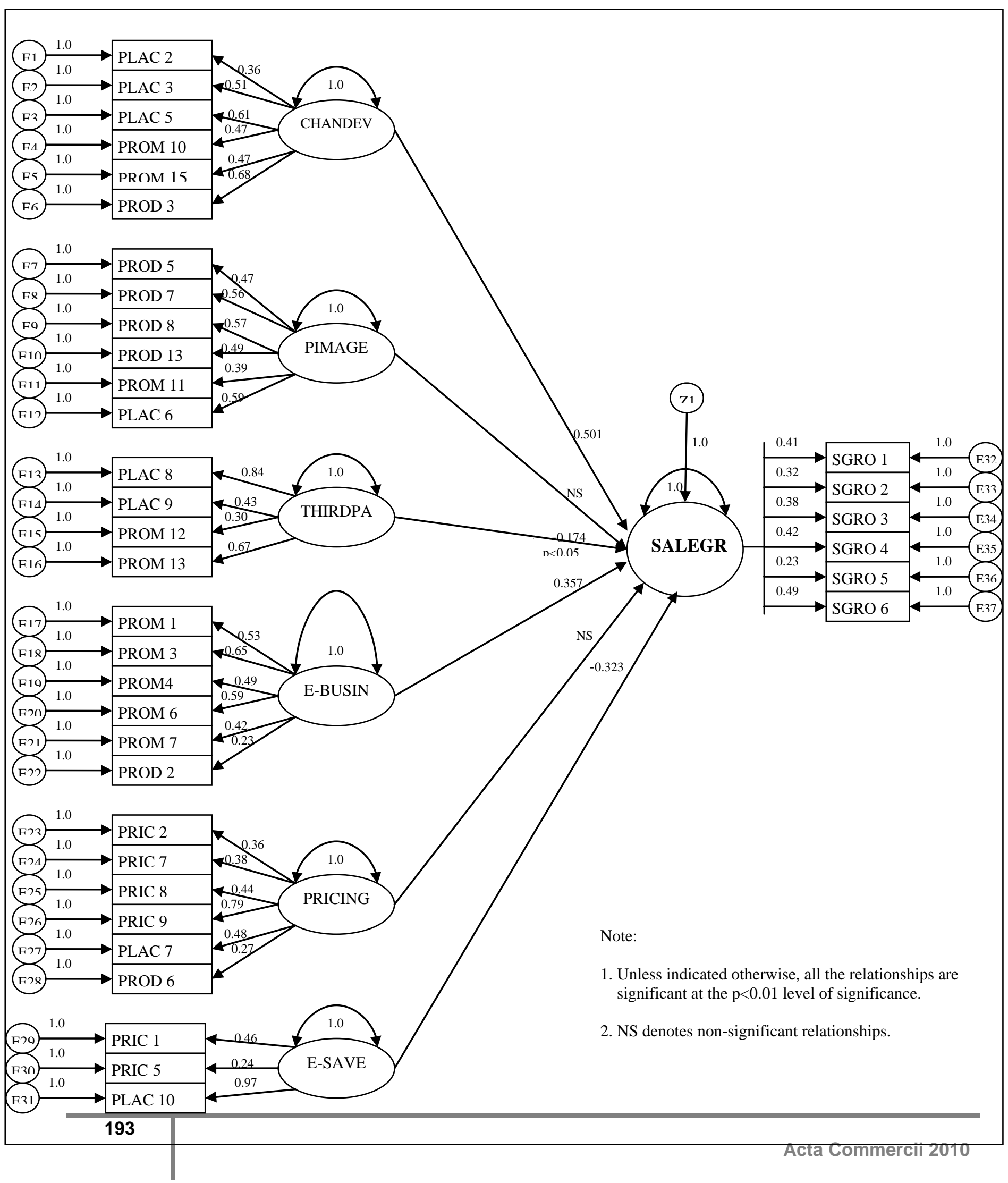


Structural equation models are models that permit an investigation into the causal relationships among latent variables or constructs. In the present study, two path models were constructed to measure the relationships between marketing strategies and organisational variables, on the one hand, and sales growth, on the other hand. The first model investigated the relationship between the marketing strategies (distribution channel development, product image, third-party agreements, e-business tactics, pricing tactics and e-saving) and sales growth. The second model investigated the influence of organisational variables (TQM, entrepreneurial organisational culture and market-oriented organisational culture) on sales growth. These models were analysed by means of the LISREL statistical software package (Jöreskog \& Sörbom, 2004).

\section{EMPIRICAL RESULTS}

The results of the structural equation analyses are reported below. These include the influence of (1) marketing strategies and (2) organisational variables (TQM, entrepreneurial organisational culture and market-oriented organisational culture) on sales growth.

\section{The influence of marketing strategies on sales growth}

The path model depicted in Figure 3 was constructed to investigate the relationship between the marketing strategies and sales growth. The empirical results are also shown in Figure 3.

The empirical results (Figure 3 ) show that distribution channel development $(0.501, p<0.01)$ and e-business $(0.357, p<01)$ are positively related to sales growth. This means that the more these strategies are used the more sales growth will be achieved.

Figure 3 also indicates that significantly negative relationships exist between e-save strategy $(-0.323, p<$ $0.01)$ and third-party agreements $(-0.174, p<0.05)$, on the one hand, and sales growth on the other hand. This means that an increased use of these tactics will result in a decrease in sales. It appears that firms need to identify and avoid the use of certain third-party agreements and e-save tactics in their endeavours to increase sales.

The empirical results further reveal that product image and pricing strategies are not significantly related to sales growth. This means that the use of these product and promotion strategies does not influence sales growth significantly.

To establish the extent to which the proposed model represents an acceptable approximation of the data, the fit indices of the model were examined. The Satorra-Bentler Chi-square, RMSEA and goodness-of-fit (GFI) indices are reported in Table 6.

Table 6: fit indices - the influence of marketing strategies on sales growth

\begin{tabular}{|l|l|l|l|}
\hline $\begin{array}{l}\text { SAMPLE SIZE } \\
\text { EXCEEDANCE }\end{array}$ & SATORRA-BENTLER CHI-SQUARE & Df & PROBABILITY \\
\hline 571 & 7158.204 & 1880 & 0.000 \\
\hline $\begin{array}{l}\text { Root mean square error of approximation (RMSEA) }=0.070 \\
\text { Goodness-of-fit index (GFI) }=0.709\end{array}$ \\
\hline
\end{tabular}

Table 6 shows that the RMSEA and GFI indices indicate acceptable levels of fit. The RMSEA (0.070) falls within the reasonable fit range of 0.05 to 0.08 , while the GFI $(0.71)$ is reasonably high in the range of zero $(0)$ to one (1).

Based on the empirical results (path coefficients), the revised hypothesis $(\mathrm{H} 1 \mathrm{~A})$, that product image exerts a positive influence on sales growth, is not supported. The empirical results however indicate that an e- 
business strategy exerts a significantly positive influence on sales growth. This result supports the revised hypothesis $\mathrm{H} 2 \mathrm{~A}$.

The empirical results also reveal that the revised hypothesis $\mathrm{H} 3 \mathrm{~A}$, that pricing strategies exert a positive influence on sales growth, is not supported. The results also indicate that place strategy (as measured by distribution channel development) exerts a positive influence respectively on sales growth, while place strategy (as measured by third-party agreements and e-saving) exerts a negative influence on sales growth. It therefore means that the revised hypothesis H4A1 is supported, while the revised hypotheses H4A2 and H4A3 are not supported.

\section{The influence of organisational variables on sales growth}

The path model depicted in Figure 4 was constructed to investigate the relationship between the organisational variables (TQM, entrepreneurial organisational culture and market-oriented organisational culture) and sales growth. The results are recorded in Figure 4.

Figure 4 shows that a market-oriented organisational culture is positively $(0.606, p<0.01)$ related to increased sales growth. This means that the more a market culture is promoted in these firms the more sales growth will be achieved. The empirical results however reveal that total quality management and an entrepreneurial organisational culture are not significantly related to sales growth. This means that the promotion of TQM and entrepreneurial culture in the selected industries would have no effect on their sales growth.

The indices of fit (see Table 7) for the model depicted in Figure 4 show acceptable levels of fit. The RMSEA (0.066) falls within the reasonable fit range of 0.05 to 0.08 , while the GFI $(0.80)$ is reasonably high in the range of zero (0) to one (1).

Table 7: fit indices - the influence of organisational variables on sales growth)

\begin{tabular}{|l|l|l|l|}
\hline $\begin{array}{l}\text { SAMPLE SIZE } \\
\text { EXCEEDANCE }\end{array}$ & SATORRA-BENTLER CHI-SQUARE & Df & PROBABILITY \\
\hline 571 & 2409.750 & 693 & 0.000 \\
\hline $\begin{array}{l}\text { Root mean square error of approximation (RMSEA) }=0.066 \\
\text { Goodness-of-fit index (GFI) }=0.805\end{array}$ \\
\hline
\end{tabular}

Based on the empirical results (path coefficients), the revised hypothesis (H6A1), that TQM) exerts a positive influence on sales growth) is not supported. Similarly, the empirical results do not support the revised hypothesis H7A that an entrepreneurial organisational culture influences sales growth positively. The empirical results however support the revised hypothesis H7B that a market-oriented organisational culture positively influences sales growth.

\section{MANAGERIAL IMPLICATIONS}

Influence of distribution channel development on sales growth

Research has shown that sales and service staff in distribution channels have the most contact with the customers and the most influence over customers' future decisions regarding product purchase and repeat product purchase (Arussy, 2006). New distribution channels based on the competitive advantage of new technologies could therefore allow more sales people to interact with potential customers, while current customers will use these channels for service. The empirical results show that by developing new channels of distribution; training the sales personnel in the firm as well as within the distribution channels; providing incentives to sales people; and using special entertainment events and using media releases to advertise distribution channels will increase sales growth. 


\section{Influence of third-party agreements on sales growth}

A third-party agreement strategy, according to the present study, should include elements such as Original Equipment Manufacturer (OEM) agreements, licensed third parties, media and public relations partners to publish success stories and beta sites and beta versions. The empirical results of the present study, however, show that third-party agreements have a negative influence $(-0.174, p<0.05)$ on sales growth.

The empirical result that third-party agreements are negatively related to sales growth is in line with McDonald's (2004: 2-4) finding among American biotech and food manufacturing firms that sales dramatically decreased due to licensed third-party agreements. Similar findings were reported by Sikora (2004: 22) about OEM agreements in the motorcar industry. An OEM is an agreement between a manufacturer and an OEM whereby the latter buys components from the manufacturer that are intended to become part of a complete system instead of an individual product (Subhash, 1993: 392). It appears that OEMs are not so keen on entering into these agreements any longer, as they are concerned about the lack of quality control over different parts arriving from different manufacturers and being put together under the package of the OEM's brand (Ben-Zaquen, 2008: 16).

According to the empirical results, beta sites and beta versions will decrease sales growth. Experiences by some high-technology manufacturers, such as Microsoft support this finding. Beta sites allow potential customers to download some software, "test drive" it and then to provide feedback to the manufacturers. Often bugs and fatal errors are found in these downloads resulting in customers not buying these software programmes, as it was the case with the beta version of the Vista operating system of Microsoft. The consequence was that the Windows Vista software programme never reached its sales goals (Demerjian, 2007; Davis, 2007). As far as the motorcar and food manufacturing industries are concerned, beta sites are not used a lot, which explains why this tactic is not regarded as a contributor to sales growth.

According to the empirical results, third-party agreements with media groups or public relations agencies for the purpose of publishing early success stories do not increase sales growth. It appears that marketing managers in the selected industries of the present study prefer a total market approach and not exclusive agreements with media and public relations agencies.

\section{Influence of e-business on sales growth}

The empirical results show that an e-business strategy has a significant influence on sales growth $(0.357, p<$ 0.01). E-business tactics include the use of websites; forums, chat rooms and news groups; e-mail; screensavers, themes, downloads and wall paper; online virtual tests; and the providing of information on quality standards. It appears that an e-business strategy is widely used in the selected industries of the present study. A decade ago, the Internet was practically unheard of by most people. Today, the Internet is one of the most powerful technologies throughout the world (Herrera, 2008). Most marketing managers have realised the importance of the Internet for creating business and introducing their products and services globally (Fletcher, Bell \& McNaughton, 2004: 266). Managers must however be aware of the disadvantages of this technology, such as dubious web security, hackers, stolen information and low Internet traffic. Managers should invest in up-to-date security software programs to minimise these threats, as a hundred percent security cannot be guaranteed.

\section{Influence of e-saving on sales growth}

In the present study, the empirical results show that an e-save strategy has a significantly negative influence on sales growth $(-0.323, p<0.01)$. E-save strategy in this study includes buy-one-get-one-free, saving packs and direct sales on the Internet and appears to be often used in the industries selected for the present study.

The e-save strategy identified in the present study boils down to the reduction of prices. Managers should be very careful when using these pricing strategies, because customers may perceive a price reduction as indicating lesser product quality or that something is wrong with the product line. In addition, lowering pricing presents a challenge to marketing managers for various reasons. Firstly, research and development (R\&D) 
costs are high and have to be paid back immediately, while funds are expected to be gathered by sales of the new product over a longer time period. Secondly, R\&D departments are expected to innovatively improve current products or develop new products. This is only possible if cash flows materialise as expected. It is therefore understandable that the e-save strategy would decrease sales and why marketing managers would try to avoid it. Zimmerman (2008) concurs that the e-save strategy, as identified in the present study, should only be considered in economic slowdowns in countries.

\section{Influence of market-oriented organisational culture on sales growth}

The empirical results show that market culture has a significant influence $(0.606, p<0.01)$ on sales growth. In other words, the results suggest that firms which driven by market-related goals; reward performance that contributes to these goals; and managing the energy resources to support the achievements of these goals will increase their sales growth. This finding is in line with Grant (2007: 171) who asserts that a global environment characterised by greater integration of businesses within a market cultural orientation leads companies to excellent performance, increased sales and improve service to customers. This finding is also supported by many reports in the high-technology (Levi, 2008), food (Fischer, 2007) and motorcar industry (Krix \& de Saint-Seine, 2006: 6). Large research and development investments, service excellence incentive programmes and the management of global and national resources are hallmarks in many firms in these industries (Cesano \& Gustafsson, 2000; Archak, Narendra \& Jyotirmay, 2004: 393-394).

To conclude: the Kotler's (2003) high-performance business model would be one that effectively manages its distribution channels and e-business tactics, as well as its market-oriented organisational culture. The generic model therefore to increase sales growth in the motorcar, high-technology and food manufacturing industries is given in Table 8.

Table 8: a generic model to increase sales growth in the motorcar, high-Technology and food manufacturing industries

MANAGE DISTRIBUTION CHANNELS EFFECTIVELY BY:

- Continuously exploring new distribution channels

- Training sales people within firm and distribution channel

- Providing incentives to sales people in distribution channel

- Using special entertainment events and media to advertise distribution channels

USE THE FOLLOWING E-BUSINESS TACTICS EFFECTIVELY:

- Websites, forums, chat rooms, news groups, e-mail, screensavers, themes, downloads, wall paper, and on-line virtual tests.

- Emphasise product quality information in the content on these tactics.

DRIVE A MARKET-ORIENTED CULTURE BY:

- Driving market-related and financial goals (sales, profit and market share) on a monthly or quarterly basis

- Rewarding performance rather than social networks

- Ensuring the availability of resources (physical and human) to deliver what customer wants.

By implementing this model, firms in the selected industries will go a long way in increasing their sales and the success of their businesses.

\section{Future research}

Although the present study has made significant contributions to the body of knowledge on how to increase sales growth, certain areas still need to be explored or expanded. These areas include assessing and testing the model on the each of the selected industries separately and using improved instruments to measure the latent variables of this model. The validity of this model should also be tested in other industries, as the recommendations appear to be applicable to all businesses. 


\section{LIST OF SOURCES}

Archak P., Narendra, K. B. \& Jyotirmay, M. 2004. Energy analysis of manufacturing process of a motorcycle. International Journal of Energy Technology and Policy, 2(4): 392-402.

Arnolds, C. A, Tait, M. \& Dayan, O. 2006. An exploratory study of the tactics used to launch high-technology products in Israel: lessons for South Africa. Management Dynamics, 15(3): 12-26.

APQC. 2007. Benchmarking: leveraging best-practice strategies. [On - line] Available: http://www.isixsigma.com (Accessed 9 August 2008).

Arussy, L. 2006. The Service I Demand - Letters From Your Customer. Second Edition. Tel Aviv: Matar.

Banson, J. J. 2002. How effectively does marketing drive business success. [On - line] Available: http://www.wnim.com (Accessed 7 December 2007).

Beckford, J. 2002. Quality. Second Edition. London: Routledge.

Ben-Zaquen, J. 2008. Value for money. [On - line] Available: http://www.pc.co.il (Accessed 3 September 2008).

Bucklin, R. E. \& Sunil, G. 1998. Market response and segmentations. Marketing Res, 29: 201215.

Callaghan, D. 2003. CRM game plan. eWeek, 20(47): 31.

Casper, C. 2007. Fewer headaches, more productivity. Logistics, 14(94): 32.

Cesano, D. \& Gustafsson, J. E. 2000. Impact of economic globalisation on water resources a source of technical, social and environmental challenges for the next decade. Stockholm: Royal Institute of Technology.

Chinho, L. \& Shofang, C. 2006. Exploring TQM's impact on the causal linkage between manufacturing objective and organizational performance. Total Quality Management \& Business Excellence, 17(4): 465-484.

Chomka, S. 2003. Sweet success. Food Manufacture, 78(5): 60.

Chow, I. H. S. \& Shan S. L. 2007. Business strategy, organizational culture, and performance outcomes in China's high technology industry. Human Resource Planning, 30(2): 47-55

Cooper, D. R. \& Schindler, P. S. 2006. Business research methods. Ninth Edition. Boston, Burr Ridge: McGraw-Hill.

Daft. R. L. 2006. The new era of management. International Student Edition. Ohio: SouthWestern.

Danaher, P. J., Hardie, B. G. S., Putsis, J. R. \& William, P. 2001. Marketing-mix variables and the diffusion of successive generations of a technological innovation. Journal of 
Marketing Research, 38(1): 43-61.

Davis, J. 2007. Pioneering MSP makes its mark. eWeek, 24(15): 16.

DelVecchio, S. K., Zemanek, J. E., Mcntyre, R. P., \& Claxton, R. P. 2003. Buyers' Perceptions of salesperson tactical approaches. Journal of Personal Selling and Sales Management, 23(1): 11-39.

Demerjian, C. 2007. Microsoft admits Vista failure. London: Incisive Media Investments.

Dignan, L. 2006. Innovation that matters. eWeek, 23(14): 40.

Evans, J. R. \& Dean, J. W. 2003. Total Quality. Third Edition. Ohio: South-Western.

Fischer, D. K. 2007. Kentucky Fried Chicken and the Global Fast-Food Industry. [On - line] Available: http://www.economist.com (Accessed 15 August 2008).

Fitzgerald, K. 2007. Activia. Advertising Age, 78(45): 2.

Fletcher, R., Bell, J. \& McNaughton, R. 2004. International e-business marketing. Cornwall: Thomson.

Frymier, L. \& Rixey, J. 2000. Natural resources - boat excise tax - certificate of title. Maryland General Assembly: Department of Legislative Services.

Gazit, M. 2002. Six Sigma: driving supply chain success at ford. Supply Chain Management Review, 6(4): 38.

Gourville, J. \& Soman, D. 2002. Pricing and the psychological of consumption. Harvard Business Review,80: 90-97.

Grant, S. B. 2007. Vulnerability to post contractual opportunism in supply chain co-operative exchange. Marketing Management Journal, 17(2): 169-189.

Gray, J. \& Hayes, K. 2007. Application of brand management techniques to professional development. [On - line] Available: http://www.worldfoodscience.org (Accessed 2 April 2007).

Guyer, L. 2006. Magazines play catch up in auto ad wars. Automotive News, 80(6205): 28.

Han, S. B., Chen, S. K. \& Ebrahimpour, M. 2007. The impact of ISO 9000 on TQM and business performance. Journal of Business \& Economic Studies, 13(2): 1-23.

Hair, J. F., Black, W. C., Babin, B. J., Anderson, R. E. \& Tatham, R. L. 2006. Multivariate data analysis. Sixth Edition. New Hersey, Prentice Hall.

Hanssens, D. M. \& Leeflang, P. S. H. 2005. Market response models and marketing practice. Applied Stochastic Models in Business \& Industry, 21(4/5): 423-434.

Hellriegel, D., Jackson, S. E. \& Slocum, J. W. 2004. Management: a competency based approach. Tenth Edition. New York: South Western College Publishing. 
Herrera, C. 2008. Advantages and Disadvantages of the Internet. [On - line] Available: http://www.sciaga.pl (Accessed 5 August 2008).

Hill, C. W. L. \& Jones, R. J. 2004. Strategic management: an integrated approach. Sixth Edition. Boston: Houghton Mifflin Company.

Jobber, D. 1998. Principles and practice of marketing. Second Edition. London: McGraw Hill.

Jöreskog, K. \& Sörbom, D. 2004. LISREL 8.7 for Windows. [Computer Software]. Lincolnwood, IL: scientific international software Inc.

Karpinski, R. 2004. Vertical Crm Products Proliferate. B to B, 89(6): 26-27.

Kooser, A. C. 2007. E-Learning Gets Practical. Restaurant Business, (106)3: 12.

Kotler, P. 2003. Marketing Management. Eleventh Edition. New Jersey: Prentice-Hall.

Kryhul, A. 2000. Bringing up baby. Marketing Magazine, 105(28): 13.

Levi, S. 2008. The story of Intel - behind the scene. [On - line] Available: http://www.globes.co.il (Accessed 16 August 2008).

MacCullum, R. C. Browne, M. W. \& Sugawara, H. M. 1996. Power analysis and determination of sample size for covariance structure modeling. Psychological Methods, 1(2): 130149.

McDonald, C. 2004. North American scientific first quarter net sales decrease 35\%. Biotech Financial Reports, 4(12): 2-4.

McElroys, J. 2005. We need a plan B. Ward's Auto World, 41(10): 21.

Morre, G. 2007. Time to Remember: Apple's failures. Ynet Technology, 6(30): 12.

Palmer, A. 2000. Principles of marketing. [On - line] Available: http://web6.epnet.com (Accessed 7 December 2007).

Pauwels, K., Silva Risso, J., Srinivasan, S. \& Hanssens, D. M. 2004. New products, sales promotion and firm value: The case of the automobile industry. Journal of Marketing, 68: 142-156.

Percy, L., Rossiter, J. R. \& Elliott, R. 2001. Strategic advertising management. [On - line] Available: http://web6.epnet.com (Accessed 9 December 2007).

Pierce, J. L. \& Dunham, R. B. 1987. Organisational commitment: pre-employment propensity and initial work experience. Journal of management, 13(1): 163-178.

Plumeri, J. 2006. Flying the Willis flag. Business Insurance, 40(44): 6.

Reyes, M. 2004. Briefs. Computerworld, 38(20): 6-8.

Sandler, L. A. \& Blanck, P. 2005. The quest to make accessibility a corporate article of faith at Microsoft. Sciences \& The Law, 23(1): 39-64. 
Schneider, M. T., Schade, B. \& Grupp, H. 2004. Innovation process "Fuel cell vehicle: what strategy promises to be most successful. Technology Analysis \& Strategic Management, 16(2): 147-172.

Seiler, M. \& Gurewitsch, S. 2005. Marketing Masters: How High Performance Businesses are Using Effective Marketing to Drive Profitable Growth. New York: Accenture.

Shaw R. \& Merrick, D. 2005. Marketing payback - is your marketing profitable. Harlow: Prentice-Hall.

Shermach, K. 2006. Cram for CRM effectiveness. Sales \& Marketing Management, 158(4): $20-$ 20.

Sikora, M. 2004. Auto Parts firms start to split replacement, OEM channels. Mergers \& Acquisitions: The Dealermaker's Journal, 39(9): 22-23.

Silva-Risso, J. M. \& Bucklin, R. E. 1999. A decision support system for planning manufacturers' sales promotion calendars. Journal of Marketing Science, 18(1): 48-82.

Simonson, I. 1999. The Effect of Product Assortment on Buyer Preferences. Journal of retailing, 75(3).

Smith, P. 2007. U.S. Deportations of illegal immigrants increase. [On - line] Available: http://www.voanews.com (Accessed 14 July 2008).

Soraya, M. 2006. History, Hoagies and the guerrilla thing. Brandweek, 47(43): 16.

Struwig, F. W. \& Stead, G. B. 2001. Planning, designing and reporting research. Cape Town: Pearson Education, South Africa.

Sullivan, J. 2007. 'Penny-wise' strategies for hiring, training and retaining staff lead to samestore sales gains. Nation's Restaurant News, 41(36): 18-56.

Tharenou, P. 1993. A test of reciprocal causality for absenteeism. Journal of organisational behaviour, 14: 269-290.

Thibodeau, P. 2006. IT managers told to think young. Computerworld, 40(42): 14.

Thomas, A. \& Lindsay, D. 2003. Organisational culture at A South African Food service company. South African Journal of Business Management, 34(4): 45-52.

Thompson, A.A., Strickland, A.J. and Gamble, J.E. (2007), Crafting and executing strategy: The quest for competitive advantag". $15^{\text {th }}$ edition. Boston: McGraw-Hill Irwin.

Torvald, G., Svein, L. \& Einar, M. 2005. Organizational culture and performance- evidence from the fast food restaurant industry. Food Service Technology, 5(1): 23-34.

Weber, S. 2008. Market-driven goal setting: using market-driven techniques to align your own quarterly and annual goals with the market. [On - line] Available: http://www.pragmaticmarketing.com (Accessed 14 October 2008). 
Weernink, W. O. 2000. Japanese choose different logistics and distribution tactics in Europe. Automotive News Europe, 5(4).

Zimmerman, A. 2008. Slowdown takes toll on target. Wall Street Journal - Eastern Edition, 251(119): B4. 